\section{Quatro crônicas de futebol de rua}

\section{Braulio Tavares}

Braulio Tavares nasceu, em 1950, em Campina Grande, Paraíba, e conviveu também intensamente com a cultura pernambucana. Mudou-se para o Rio de Janeiro em 1982, onde vive até os dias de hoje. É ficcionista, poeta,

dramaturgo, tradutor, pesquisador de literaturas fantástica e de cordel, compositor e letrista, destacando-se suas par-

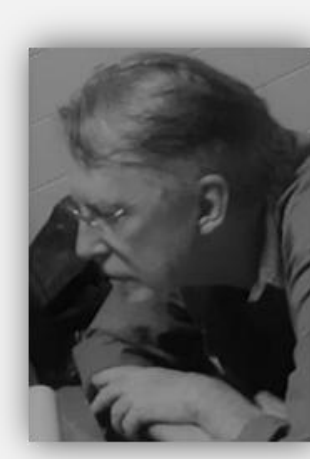
cerias com Lenine.

É organizador das antologias Contos fantásticos no labirinto de Borges (2005), Freud e o estranho: contos fantásticos do inconsciente (2007) e Contos obscuros de Edgar Allan Poe (2010). Vencedor do Prêmio Jabuti de Literatura Infantil, em 2009, pela obra A invenção do mundo pelo Deus-Curumim, em parceria com Fernando Vilela.
Publicou, dentre outras dezenas de livros, $A$ espinha dorsal da memória (1989) - contos -, vencedor da premiação portuguesa Caminho da Ficção Científica, A máquina voadora (1994) - romance -, O que é Ficção Científica (1986) - ensaio -, pela editora Brasiliense, e $O$ homem artificial: poemas (1999) e $O$ poder da natureza (2013) - poesia.

Braulio Tavares foi cronista semanal do jornal paraibano Jornal da Paraíba, onde foram publicas estas quatro crônicas em sua coluna, "Pelada e democracia", "O futebol segundo Jairzinho", "O lateral-esquerdo suspeitoso" e "O barra-abarra", que bem nos dizem sobre o futebol praticado ludicamente nas ruas pela garotada. 
Pelada e democracia - 9 mar. 2005

Não existe nada mais educativo sobre o que é democracia do que um jogo de pelada.

Democracia não é Republicanismo, o qual é apenas uma das modalidades políticas de sua prática. É qualquer situação em que interesses coletivos são administrados através de um debate onde todos têm voz ativa, e onde o resultado final, se não é um consenso unânime, é pelo menos uma solução com que a maioria concorda e a minoria se conforma.

Não existe conceito filosófico mais impreciso do que o conceito peladeiro de "bola fora". 0 campo não tem linhas. Às vezes o "fora" é determinado por alguns arbustos: bola entrou no mato, é fora. Às vezes é o trecho onde acaba a grama e começa a terra, ou onde acaba a areia e começa o cascalho. Toda vez que a bola passa por ali, ergue-se o coro: “Foi fora!” “Não foi!".

No futebol de verdade, a "barra" é de uma nitidez impecável, cartesiana. É um quadrilátero formado por três traves e uma linha de cal: passou dali é gol, e para o caso de uma bola muito rápida, tem a rede para detê-la e confirmar a trajetória.
Mas as barras que na adolescência eu alvejei como atacante ou defendi como goleiro eram duas sandálias enfiadas na areia, ou duas pedras, ou dois montes de roupas. Na pela$\mathrm{da}$, a gente é forçada a visualizar traves virtuais e tentar colocar o chute não apenas fora do alcance do goleiro (como fazem os jogadores de verdade) mas de preferência longe das traves invisíveis, longe daquilo que sabemos ser o território da reclamação.

Na pelada, um gol só é indiscutível se passar pertinho do chão, e a pelo menos um palmo para dentro da "trave".

Na pelada não há bola na trave, há o famoso "por cima", ou seja, por cima da pedra. Não é gol. E como não há travessão (superior), a altura dessa barra virtual é definida pela capacidade de salto do goleiro. Se a bola for numa altura que o goleiro visivelmente não alcançaria, foi fora. Um goleiro de 1,50 e outro de 1,70 estão, numa mesma partida, defendendo barras proporcionais a seu tamanho e seu salto.

E tem mais uma: quando o goleiro pula para o alto e toca na bola, valida o gol, porque provou que o chute não era alto assim. Muito goleiro de pelada tenta "dar uma de migué" 
e fingir que pula, evitando alcançar a bola, para poder dizer que foi bola alta.

Uma pelada é o exemplo típico de como grupos antagônicos resolvem conflitos oriundos de regras pouco claras. E isto é um dos pontos essenciais da democracia, porque você não pode estabelecer regras nítidas e cristalinas para tudo no mundo.

Na resolução desses conflitos, vigoram os recursos que mandam numa democracia: papo-pra-derrubar-avião, veemência, pressão, barganha ("se aquela outra não foi gol, essa aqui também não foi"), carisma, credibilidade... e malandragem, capacidade para mentir na-cara-de-pau ("juro que não foi com a mão!").

Democracia não é o governo do povo, é o governo do texto, o governo dos mais hábeis, dos que melhor convencem os demais a aceitar sua versão dos fatos.
O futebol segundo Jairzinho - 12 set. 2010

Minha convicção, até prova em contrário, é de que jornalismo se aprende na redação, natação na água e futebol no campo. Este último merece detalhamento. Campo não é um gramado impecável, onde um garoto calça chuteiras e ganha intimidade com uma bola de couro, Jabulani ou não. Campo é o campinho, o campinho de terra ou de capim, ou mesmo uma rua calçada de pedras, onde garotos descalços jogam com qualquer coisa que possa ser imaginada como uma bola.

Numa entrevista recente ao Globo, Jairzinho, campeão do mundo em 1970, resume essa raiz popular do futebol de maneira irretocável: "O futebol moleque acabou, o futebol formado num ambiente livre, natural. Eu mesmo fui formado assim. Nas praias, Urca, Praia Vermelha, Praia do Leme; nos terrenos baldios, que ainda existiam; nas praças também. E na própria rua, numa época em que não havia congestionamento de carros. Comecei brincando com laranja, depois com bola de meia, depois com bola de borracha, toda essa evolução natural, entende? Hoje, para você encontrar um espaço é muito 
difícil. Não tem mais o campo natural, onde o garoto possa jogar sem cobrança. Se os garotos não forem para praia, vão para o futebol, o futsal e com isto perdem a naturalidade. Porque já tem um professor ali e a bola já é bem diferente. 0 importante é você começar a ter o contato (com a bola) com o pé descalço".

O que faz o jogador brasileiro ser diferente? (Não só brasileiro, claro. 0 que acontece aqui pode acontecer em praticamente qualquer lugar do mundo. Mas aqui ocorre de maneira maciça e generalizada - ou pelo menos acontecia). Primeira coisa: jogar na rua, aprender a correr em qualquer tipo de espaço, cercado pelos obstáculos mais imprevisíveis. Carros estacionados, carros em movimento, muros, árvores, postes, tocos de pau, buracos, pilhas de tijolos... Garotos jogam, há um século, em lugares assim, e é lá que aprendem a correr com ou sem a bola nos pés, a negacear, a fugir, a perseguir o atacante, a chutar, a defender, a passar, a cruzar. 0 senso de espaço é enriquecido de maneira espantosa.

Segundo: jogar sem cobrança, por vontade própria, diversão, espírito lúdico. Profissionalismo é importante, mas vem depois, e tem que vir sobre um alicerce prazeroso. Tudo que um garoto ou adulto faz por mero prazer ele fará incansavelmente, repetidamente, incessantemente, variadamente, concentradamente, dedicadamente.

Terceiro: o pé descalço e a bola de meia. Os músculos, o sistema motor e os reflexos se enriquecem ao serem testados de mil maneiras diferentes, preparando-se para as meras 100 ou 150 maneiras que lhes serão exigidas na vida adulta, na mordomia da grama, da chuteira e da bola de couro. Futebol profissional tem uma faixa de probabilidades mais estreita do que a de uma pelada de rua. Um garoto se torna $\mathrm{PhD}$ em futebol jogando com laranja chupada num campinho de terra, e a maestria assim adquirida será o alicerce para o profissional em que um dia se tornará. 
O lateral-esquerdo suspeitoso - 13 jun. 2006

Ariano Suassuna conta que na adolescência gostava de futebol mas era um verdadeiro perna-de-pau. Quando era estudante do Colégio Americano Batista, só jogava porque era amigo do capitão do time, Isaac Ribeiro.

Isaac procurava mantê-lo longe das duas áreas, para não fazer muita besteira, e o escalava como lateral-esquerdo, aconselhando: "Quando a bola chegar perto de você, chute pra fora. Se o jogador chegar perto, faça uma falta". E ele obedecia.

Um dia, fez tantas faltas que o ponta-direita adversário se irritou, deu-lhe um murro e foi expulso. 0 time de Ariano ficou com um a mais e acabou ganhando.

Noutra ocasião, a bola passou por perto e ele, apavorado, encheu o pé, mandando-a para a frente, o mais longe possível. Aí deu as costas, saiu andando, e quando viu o time todo pulou em cima dele, derrubando-o no chão, e o amigo Isaac berrava: “Arretado, tu fizesse um gol!" Foi o gol da vitória. E o artilheiro confessa, com candura: "Eu tive uma emoção tão grande que vomitei".
Para sorte da Literatura Brasileira, isso se deu lá pelos anos 1940. Se fosse hoje, o jovem estudante teria grandes chances de fazer um teste no Sport, ser aprovado, e virar jogador profissional. Porque, vamos e venhamos, a maioria dos jogadores que vemos disputando o Campeonato Brasileiro parece ter recebido as mesmas instruções que Ariano recebia de Isaac, e tentam cumpri-las à risca.

Eu tenho uma verdadeira alergia mental a futebol mal jogado (há razões freudianas para isto: sou tão perna-de-pau quanto Ariano), e mesmo nas grandes equipes brasileiras e europeias tem jogadores que eu fico matutando quem diabo colocou aquele cara ali.

São brucutus, brutamontes, arranca-tocos, massas de ossos e músculos com duas chuteiras numa extremidade e uma careca na outra. Estão por toda parte, inclusive Barcelona, Real Madrid, Milan, Arsenal, Liverpool, qualquer time bom que a gente vê jogando.

Um lado maldoso que tenho em mim me explica que é a globalização do futebol, a busca permanente dos resultados. E a verdade é que, digam o que disserem os idealistas como 
eu, muitas vezes você garante um resultado chutando a bola para fora e fazendo falta no ponta.

Às vezes cabe até a um sujeito assim fazer o gol que fica na história, como ocorreu com o Ariano e também com Belletti, no Barcelona. São jogadores no diapasão "da garra, da determinação e da busca-do-objetivo".

Existe, contudo, um lado poético que me diz o contrário. 0 futebol é algo tão belo e fascinante que desperta paixão até mesmo nos que a Natureza não aparelhou para praticá-lo. Esses jogadores amam o futebol com o amor bronco e troglodita de Zampanò por Gelsomina em La Strada de Fellini: amam-no por ser a promessa de uma beleza e uma inocência que lhes é para sempre vedada.

Ergo um brinde à arte do futebol, uma arte tão bela que até mesmo nós, os pernas-de-pau, que não jogamos nada, enchemos os olhos de lágrimas quando o vemos ser bem jogado.
O barra-a-barra - 4 ago. 2004

O futebol de salão foi inventado no Brasil, mas ninguém ainda nos deu o crédito, ao que eu saiba, por uma das mais curiosas mutações do jogo de futebol. Refiro-me ao "barra-a-barra", uma interessante variante popular do jogo oficial. Joguei barra-a-barra a vida inteira, e até os 18 anos ainda travava disputas ferozes com meu irmão Pedro, numa sucessão infindável de partidas que terminavam sempre com "a do banho", a saideira cujo vencedor tinha o direito de tomar banho primeiro, enquanto o outro ficava, suado, esperando o chuveiro desocupar.

O barra-a-barra é uma demonstração de como funciona a cultura popular. 0 futebol é um jogo regulamentado, com regras especificando tamanho do campo, linhas demarcatórias de espaços, número de jogadores, etc. A essência do futebol, contudo, não são essas regras. A essência do futebol é: colocar uma bola, sem usar as mãos, num espaço defendido pelo adversário, e impedir que ele faça o mesmo conosco. Em cima desta premissa, constrói-se tanto o universo das regras 
quanto o universo das manobras físicas (chutes, cabeçadas, dribles e tudo o mais).

As regras do barra-a-barra são simples. Num espaço aberto, a barra pode ser marcada por duas pedras ou dois montes de roupas, como numa pelada qualquer. Num espaço fechado (um quarto, por exemplo), podem ser duas paredes opostas. Existe o barra-a-barra de pé, e o barra-a-barra de cabeça. No primeiro, é simples: cada um tem direito a um chute, como se fosse uma disputa de pênaltis recíprocos. 0 barraa-barra de cabeça é mais interessante: joga-se a bola para o alto e desfere-se uma cabeçada na direção do gol adversário. As duas modalidades têm acréscimos interessantes: o mata e o queima. 0 mata significa que quando o adversário chuta ou cabeceia e a gente consegue matar a bola no peito, daí em diante vira um jogo de verdade, ambos disputando a bola como num jogo normal, e ambos com a possibilidade de fazer o gol na barra do oponente. 0 queima significa que quando a gente chuta ou cabeceia e o adversário não consegue segurar (ele "queima", ou "arrota", a bola), a gente pode fazer o gol, mas ele não - ele continua a ser apenas goleiro, tem que voltar a segurar a bola.

As sutilezas deste jogo encheriam livros. Quero apenas lembrar que a Cultura de Rua é mestra nesse tipo de coisa. Não é por falta de 22 jogadores que alguém deixa de jogar futebol; não é por falta de grama; não é por falta de linhas ou de traves. As pessoas encontram um jeito de "distorcer", "deturpar" uma atividade em seu benefício. Pessoas de índole purista detestam essas "deformações", mas elas são inevitáveis e são necessárias. Legisladores futebolísticos britânicos do século 19 talvez ficassem horrorizados diante de uma variante plebeia como o barra-a-barra. Talvez dessem um jeito de proibi-lo na Constituição, transformá-lo em crime ou contravenção. Não adianta. A Rua assimila, aprende, desconstrói, reformata, recompõe, ensina e bota pra rodar. 